\title{
UJI EFEK EKSTRAK ETANOL 96\% ANGGUR MERAH (Vitis vinifera) TERHADAP PENURUNAN KADAR TRIGLISERIDA PADA TIKUS PUTIH (Rattus Novergicus) YANG DIINDUKSI TRITON X-100
}

\section{THE EFFECT OF 96\% ETHANOL EXTRACT OF RED GRAPE (VITIS VINIFERA) ON REDUCING BLOOD TRIGLYCERIDE LEVELS ON RATUS NOVERGICUSINDUCED BY TRITON X}

\author{
Frans Saputra, EM Sutrisna, Nurhayani \\ Fakultas Kedokteran Universitas Muhammadiyah Surakarta \\ Korespondensi: DR.dr.Em Sutrisna, Email:Em.Sutrisna@ums.ac.id
}

\begin{abstract}
ABSTRAK
Buah anggur merah diduga memiliki kandungan pterostilbene, resveratrol, proantosianidin dan likopen yang memiliki efek terhadap penurunan kadar trigliserida. Penelitian ini bersifat eksperimental laboratorium dengan metode pre and post test with control group design. Objek penelitian 25 ekor tikus putih jantan, Rattus Novergicus, berat badan 150-200 gram, berumur 3-4 bulan yang dibagi menjadi 5 kelompok dengan teknik simple random sampling, kontrol negatif (aquadest), kontrol positif (Simvastatin 0,2mg/200gramBB/hari), kelompok perlakuan dosis I (100mg/200gramBB/hari), dosis II (250mg/200gramBB/hari), dosis III (500mg/200gramBB/ hari). Ekstrak etanol anggur merah dosis I, dosis II, dosis IIIdapat menurunkan kadar trigliserida darah dengan rerata penurunan secara berturut-turut adalah 147,4mg/dL, 135,2mg/dL, 97,2mg/dL. Pada uji statistik menggunakan one-way ANOVA didapatkan nilai $p=0,000(p<0,05)$, sehingga terdapat perbedaan signifikan kadar trigliserida darah tikus putih antar kelompok. Ekstrak etanol 96\% anggur merah dosis $100 m g ; 250$ dan 500 /200 gramBB/hari dapat menurunkan kadar trigliserida darah tikus putih.
\end{abstract}

Kata kunci :Ekstrak Anggur Merah, Trigliserida, Rattus Novergicus

\section{ABSTRACT}

Red grape contains pterostilbine, reservatrol, proantocianidine and lycopene which is allegedly to have effect on reducing triglyceride levels. This study was a laboratorium experimental study with a pre and post test with control group design. The subjects were 25 male white rats (Rattus novergicus), body weight 150-200 grams, aged 3-4 months, and divided into 5 groups with simple random sampling. The groups were negative control (aquadest), positive control (simvastatin 0,2 $\mathrm{mg} / 200 \mathrm{gram} \mathrm{BW/day),} \mathrm{dose} \mathrm{I} \mathrm{(100} \mathrm{mg/200} \mathrm{gram} \mathrm{BW/day),} \mathrm{dose} \mathrm{II}$ (250 mg/200 gram BW/day) and dose III (500 mg/200 gram BW/day). The $96 \%$ ethanol extract of red grape dose I, dose II and dose III are found effective on reducing blood triglyceride levels with a mean reduction of 147,5 mg/ $d l, 135,2 \mathrm{mg} / \mathrm{dl}$ and 97,2 $\mathrm{mg} / \mathrm{dl}$, respectively. On the statistical analysis using one-way ANOVA, it is found that $p=$ $0,000(p<0,05)$. There is a significant difference of triglyceride levels among each group. The 96\% ethanol extract of red grape at dose of 100mg; 250 dan 500/200 gram bodyweight/day can reduce blood triglyceride levels in white rats (Rattus novergicus).

Keywords :Red Grape Extract, Triglyceride, Rattus Novergicus

\section{PENDAHULUAN}

Pola hidup konsumsi makanan yang tinggi kandungan lemak dan kolesterol dapat menyebabkan kadar lemak dan kolesterol di dalam darah menjadi lebih tinggi dari normal(Nasution, 2013). Tanpa disadari konsumsi makanan tinggi lemak dan kolesterol terus-menerus dapat menimbulkan penyakit degeneratif antara lain jantung koroner, dislipidemia, stroke dan diabetes Mellitus (Hidayatulloh et al., 2011).

Penyakit Jantung Koroner (PJK) masih menjadi pembunuh pertama di dunia dan tercatat 
hingga tahun 2008, PJK menempati urutan ke-1 dari 10 penyakit tersering penyebab kematian (WHO, 2011). Penyakit jantung koroner pada tahun 1972 berada pada urutan ke-11 mengalami pergeseran pada lima tahun terakhir menjadi ke-3 pada tahun 1986 kemudian menempati urutan pertama pada tahun 2001 penyebab kematian di Indonesia (Kanwil Depkes RI, 2007).

Faktor terjadinya penyakit jantung koroner akibat penimbunan plak lipida dalam dinding arteri menyebabkan penyempitan pembuluh darah (arterosklerosis). Tingginya kadar kolesterol total, LDL (Low Density Lipoprotein) dan trigliserida serta rendahnya kadar HDL (High Density Lipoprotein) mengakibatkan tingginya kadar lipid dalam darah (Tsalissavrina et al., 2006).

Statin merupakan golongan obat yang digunakan dalam menurunkan kadar lipid. Statin bekerja dengan cara menghambat sintesis kolesterol dan peningkatan jumlah reseptor LDL pada membran sel hati (Aaronson dan Jeremy, 2010). Statin mempunyai efek samping yang serius seperti miopati dan hepatotoksik. Oleh karena itu, pengembangan pengobatan baru diperlukan untuk menurunkan kadar lipid (Kim et al., 2014).

Anggur merah (vitis vinifera) memiliki beberapa kandungan antara lain antosianin, proantosianidin, prosianida, flavonoid, polifenol, resveratrol (Nassiri dan Hosseintadeh, 2009)dan likopen (Winarsi, 2007). Resveratrol ditemukan pada kulit buah anggur yang dapat menghambat akumulasi lipid dalam tubuh (Szkudelska et al., 2009). Pterostilbene merupakan salah satu kandungan dalam buah anggur yang memiliki efek farmakologi (Amr, 2010). Pterostilbene telah menunjukkan banyak manfaat protektif terhadap aterosklerosis (Cormack dan David, 2013).

Penelitian terdahulu yang dilakukan oleh Riayani (2011) menunjukkan bahwa pemberian ekstrak anggur merah dapat menurunkan kadar kolesterol total pada tikus putih. Penelitian Orbayinah dan Kurnia (2011) menunjukkan bahwa ekstrak anggur merah mempunyai efek terhadap penurunan kadar trigliserida darah tikus putih.

Berdasarkan penjelasan diatas bahwa pentingnya penelitian untuk menemukan pengobatan herbal terhadap penurunan kadar trigliserida, sehingga penulis tertarik melakukukan penelitian dengan judul “ Uji Efektifitas Ekstrak Etanol 96\% Anggur Merah (Vitis Vinifera) Terhadap Penurunan Kadar Trigliserida Darah Pada Tikus Putih (Rattus Novergicus) Yang Diberi Pakan Hiperkolesterolemia Dan Diinduksi Triton X-100”.

Tujuan yang ingin dicapai dalam penelitian ini adalah mengetahui efek ekstrak etanol 96\% anggur merah (Vitis Vinifera) Terhadap penurunan kadar trigliserida darah pada tikus putih (Rattus Novergicus) yang diberi pakan hiperkolesterolemia dan diinduksi triton $\mathrm{x}-100$.

\section{METODE}

Penelitian ini merupakan penelitian eksperimental laboratorium dengan desain pre and post test control group design. Perlakuan pada tikus di Laboratorium Farmakologi Fakultas Kedokteran Universitas Muhammadiyah Surakarta, sedangkan pemeriksaan kadar trigliserida dilakukan di Laboratorium CITO Surakarta. Hewan uji yang digunakan adalah tikus putih jantan Rattus Novergicus sebanyak 25 ekor, berusia 3-4 bulan dengan berat 150-200 gram yang diperoleh dari Laboratorium Farmakologi Fakultas Kedokteran Universitas Muhammadiyah Surakarta. Teknik pengambilan sampel dengan teknik simple random sampling, tikus putih dibagi menjadi 5 kelompok kelompok $\mathrm{K}_{1}$ sebagai kontrol negatif, kelompok $\mathrm{K}_{2}$ sebagai kontrol positif, sedangkan kelompok $\mathrm{P}_{1}, \mathrm{P}_{2}$ dan $\mathrm{P}_{3}$ sebagai kelompok perlakuan.Penentuan besar sampel setiap kelompok ditentukan berdasarkan rumus perhitungan Federer yang diperoleh hasil minimal 5 ekor tikus putih perkelompok (5 kelompok). Identifikasi variabel terdiri dari variabel bebas : dosis ekstrak anggur merah (Vitis Vinifera) (skala rasio), variabel terikat : kadar trigliserida (skala rasio). Alat yang digunakan : kandang beserta kelengkapan pemberian makanan, sonde lambung, spuit injeksi, timbangan sartorius. Bahan yang digunakan : ekstrak anggur, pakan standar pellet BR-2, pakan hiperkolesterolemia, triton x-100, simvastatin $10 \mathrm{mg}$, akuades.

\section{Cara Kerja :}

Langkah 1 : Prosedur pembuatan ekstrak anggur :Buah anggur yang dicuci bersih di bawah air 
mengalir, buah anggur diiris tipis, irisan buah anggur dijemur ditempat teduh hingga irisan buah anggur berubah menjadi kering, buah anggur yang telah kering kemudian dihancurkan hingga berbentuk serbuk, serbuk anggur direndam etanol 96\% dengan perbandingan 1:7 selama 3-4 hari, rendaman disaring dengan corong gelas yang telah dilapisi kertas saring dan didapatkan ekstrak anggur 1, residu dimaserasi ulang dengan etanol 96\% dengan perbandingan 1:4 selama 3-4 hari, rendaman disaring dengan corong gelas yang telah dilapisi kertas saring dan didapatkan ekstrak anggur 2, ektrak anggur 1 dicampurkan dengan ekstrak anggur 2, ekstrak anggur cair diuapkan dengan menggunakan rotary evaporator hingga didapatkan ekstrak kental, dosis 1 kelompok perlakuan 1 diberikan ekstrak anggur $2 \mathrm{ml} /$ ekor dengan dosis pemberian $100 \mathrm{mg} / 200$ gramBB, dosis 2 kelompok perlakuan 2 diberikan ekstrak anggur $2 \mathrm{ml} /$ ekor dengan dosis pemberian $250 \mathrm{mg} / 200$ gramBB, dosis 3 kelompok perlakuan 3 diberikan ekstrak anggur $2 \mathrm{ml} /$ ekor dengan dosis pemberian $500 \mathrm{mg} / 200$ gramBB.

Langkah II : Prosedur pembuatan pakan hiperkolesterolemia : pakan hiperkolesterolemia dengan komposisi lemak kambing $100 \mathrm{~g}$ (10\%), kuning telur 50g (5\%), pakan standar $1000 \mathrm{~g}$. Lemak kambing dipanaskan sampai mencair, dan kuning telur diambil dari telur yang telah direbus kemudian dicampur dengan pakan standar dan diberikan secara ad libitum selama 3 hari.

Langkah III : Membuat larutan simvastatin : simvastatin dibuat dalam bentuk larutan dengan cara melarutkan $10 \mathrm{mg}$ (1 tablet) simvastatin dalam $100 \mathrm{ml}$ pelarut (akuades), sehingga dalam $1 \mathrm{ml}$ terkandung $0,1 \mathrm{mg}$ simvastatin. Dosis yang digunakan buat tikus dengan berat rata-rata 200 gram yaitu $0,2 \mathrm{mg} /$ hari.

Langkah IV : Triton X-100 diberikan secara intraperitoneal dengan dosis tunggal 20 mg/200gBB (Manodeep et al., 2012).

Langkah $\mathbf{V}$ : Pemberian perlakuan pada kelima kelompok : $\mathrm{K}_{1}$ pemberian pakan hiperkolesterolemik dan diinduksi Triton X-100 dengan dosis $20 \mathrm{mg} / 200 \mathrm{gBB}$ sampai hari ke $3, \mathrm{~K}_{2}$ pemberian pakan hiperkolesterolemik dan diinduksi Triton X-100 dengan dosis 20 $\mathrm{mg} / 200 \mathrm{gBB}$ sampai harike 3 dilanjutkan pemberian simvastatin $2 \mathrm{ml}$ sampai hari ke 13, $\mathrm{P}_{1}$ pemberian pakan hiperkolesterolemik dan diinduksi Triton X-100 dengan dosis $20 \mathrm{mg} / 200 \mathrm{gBB}$ sampai hari ke 3 dilanjutkan pemberian ekstrak anggur dosis 1 sampai hari ke $13, \mathrm{P}_{2}$ pemberian pakan hiperkolesterolemik dan diinduksi Triton $\mathrm{X}-100$ dengan dosis $20 \mathrm{mg} / 200 \mathrm{gBB}$ sampai hari ke 3 dilanjutkan pemberian ekstrak anggur dosis 2 sampai hari ke 13, $\mathrm{P}_{3}$ pemberian pakan hiperkolesterolemik dan diinduksi Triton X-100 dengan dosis $20 \mathrm{mg} / 200 \mathrm{gBB}$ sampai hari ke 3 dilanjutkan pemberian ekstrak anggur dosis 3 sampai hari ke 13.

Langkah VI : Pengukuran kadar trigliserida dan analisis hasil pengukuran kadar trigliseridasecara statistik.

\section{HASIL DAN PEMBAHASAN}

Determinasi Tanaman

Determinasi tanaman dilakukan untuk identifikasi tanaman sehingga menghindari kesalahan dalam pengambilan tanaman. Kebenaran tanaman merupakan syarat yang harus dipenuhi dalam uji farmakologi terhadap tanaman tersebut. Determinasi tanaman dilakukan di Laboratorium Biologi Fakultas Keguruan dan Ilmu Pendidikan Universitas Muhammadiyah Surakarta.

Hasil determinasi tanaman Anggur Merah sebagai berikut :

$1 b, 2 b, 3 b, 4 b, 12 b, 13 b, 14 b, 17 b, 17 b, 18 b$, 19b, 20b, 21b, 22b, 23b, 24b, 25b, 26b, 27a, 28b, 29b, 30b, 31a, 32b, 74b, 631b, 632b, 633a, 634b, 635b, 636b, 637b, 638b, 694a, 695b, 696c, 705b, 711b, 719a, 720a.
Famili : Vitaceae
Genus : Vitis
Spesies : Vitis Vinifera L.

\section{Randemen}

Randemen ekstrak digunakan untuk membandingkan antara ekstrak dengan simplisia (anggur merah). Didapatkan hasil 1 gram kulit, daging dan biji anggur merah kering $=0,22$ gram ekstrak kental. 
Hasil Pengukuran Berat Badan Tikus

Tabel 1. Rerata berat badan tikus putih selama perlakuan/10 hari (gram).

\begin{tabular}{lccccc}
\hline \multicolumn{1}{c}{ Kelompok } & Hari 1 & Hari 4 & & Hari 8 & \\
\hline Kontrol Negatif & 195,2 & & 196,4 & & 196,8 \\
Kontrol Positif & 174,3 & & 174,2 & & 169,6 \\
Perlakuan 1 & 201 & & 195,2 & & 188,4 \\
Perlakuan 2 & 176,6 & 174,2 & & 160,2 & \\
Perlakuan 3 & 194,2 & 184,6 & & 165,4 & \\
\hline
\end{tabular}

Sumber : Data Primer, 2015

Pada uji ANOVA hasil penimbangan berat $(\mathrm{p}>0,05)$ dengan demikian tidak terdapat badan tikus kelompok KN, KP, P1, P2, P3 selama perbedaan berat badan secara signifikan setelah penelitian didapatkan hasil nilai probabilitas perlakuan.

Hasil Uji Efek Ekstrak Terhadap Penurunan Kadar Trigliserida

Tabel 2. Analisa deskriptif kadar trigliserida darah

\begin{tabular}{lcc}
\hline & Kelompok & \multicolumn{2}{c}{ Kadar trigliserida darah (mg/dL) } \\
\cline { 2 - 3 } & Pre-test & Post-test \\
\cline { 2 - 3 } KN & 141,4 & 164 \\
KP & 161 & 102,2 \\
P1 & 146,4 & 147,4 \\
P2 & 151 & 135,2 \\
P3 & 135 & 97,2 \\
\hline
\end{tabular}

Sumber : Data Primer, 2015

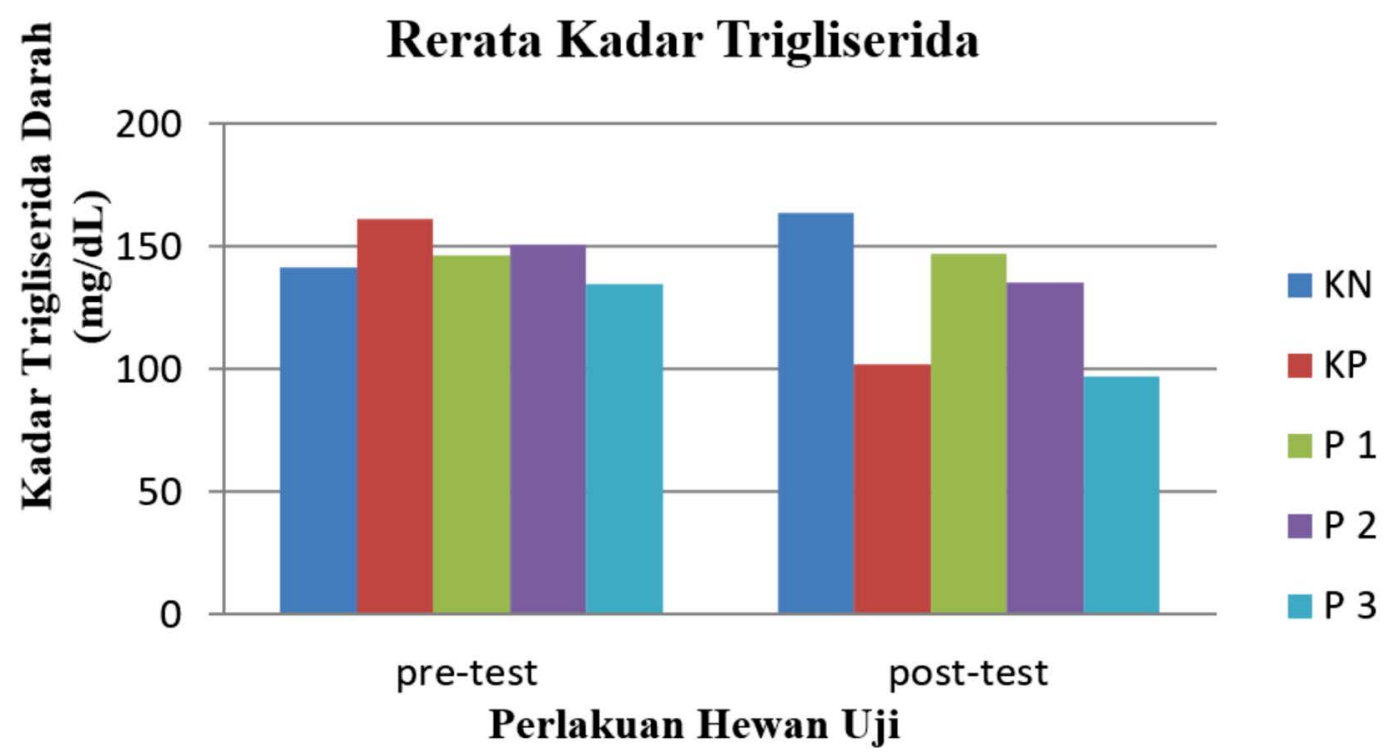

Gambar 1.Diagram rata-rata kadar trigliserida pre and post-test 


\section{Hasil Uji Distribusi Data}

Uji distribusi data menggunakan Uji Saphiro-Wilk, uji tersebut digunakan untuk mengetahui distribusi data kelompok yang kurang dari 50 sampel. Hasil analisis Saphiro-Wilk didapatkan nilai $\mathrm{p}=0,356$ $(\mathrm{p}>0,05)$. Maka disimpulkan bahwa data berdistribusi normal.

2. Hasil Uji Test of Homogenecity of Varians

Uji homogenitas varian dilakukan dengan menggunakan uji statistik Levene Test of Varians. Hasil dari uji ini didapatkan nilai $\mathrm{p}=0,095(\mathrm{p}>0,05)$ yang menunjukkan data adalah homogen.

\section{Hasil Uji one way ANOVA}

Pada analisis data menggunakan uji one way ANOVA didapatkan hasil nilai $\mathrm{P}=0,000$. Nilai probabilitas merupakan parameter untuk mengambilkeputusan.Dari hasil uji one way ANOVA menunjukkan hasil nilai probabilitas $<0,05$ maka dalam penelitian ini ekstrak etanol $96 \%$ anggur merah (Vitis Vinifera) berpengaruh signifikan dalam menurunkan kadar trigliserida darah tikus putih (Rattus Novergicus).

\section{Hasil Uji Least Significant Difference(LSD)}

Tabel 3. Uji Post Hoc Least Significant Difference (LSD)

\begin{tabular}{lll}
\hline \multicolumn{1}{c}{ Kelompok Perlakuan } & \multicolumn{1}{c}{ Nilai P } & \multicolumn{1}{c}{ Hasil Uji } \\
\hline KN-KP & 0,000 & Berbeda bermakna \\
KN-P1 & 0,011 & Berbeda bermakna \\
KN-P2 & 0,000 & Berbeda bermakna \\
KN-P3 & 0,000 & Berbeda bermakna \\
KP-P1 & 0,000 & Berbeda bermakna \\
KP-P2 & 0,000 & Berbeda bermakna \\
KP-P3 & 0,406 & Tidak berbeda bermakna \\
P1-P2 & 0,051 & Tidak berbeda bermakna \\
P1-P3 & 0,000 & Berbeda bermakna \\
P2-P3 & 0,000 & Berbeda bermakna \\
\hline
\end{tabular}

Percobaan yang dilakukan di Laboratorium Farmakologi Universitas Muhammadiyah Surakarta ini bertujuan untuk mengetahui ada tidaknya efek ekstrak etanol 96\% anggur merah (Vitis Vinifera) terhadap penurunan kadar trigliserida darah tikus putih (Rattus Novergicus) yang diberi pakan hiperkolesterolemia dan diinduksi triton $\mathrm{x}-100$. Penelitian ini menggunakan 5 kelompok tikus, setiap kelompok tikus terdapat 5 ekor. Kelompok I sebagai kontrol negatif, kelompok II sebagai kontrol positif (simvastatin dosis $0,2 \mathrm{mg} / 200$ gramBB), kelompok III sebagai kelompok perlakuan dosis I (100mg/200gramBB), kelompok IV sebagai kelompok perlakuan dosis II (250mg/200gramBB) dan kelompok $\mathrm{V}$ sebagai kelompok perlakuan dosis III (500mg/200gramBB).
Kadar trigliserida darah diukur 3 kali saat penelitian berlangsung. Kadar awal diukur pada hari pertama penelitian dimaksudkan sebagai nilai rujukan normal kadar trigliserida pada tikus yang mana nanti akan dibandingkan terhadap pengukuran kadar trigliserida setelah diberikan pakar hiperkolesterolemia dan diinduksi triton x-100 (pre-test) selanjutnya di lakukan uji t untuk melihat perbedaan pada penghitungan trigliserida awal penelitian dan pre-test/post pemberian pakan hiperkolesterolemia dan diinduksi triton x-100.

Pada uji penurunan kadar trigliserida darah dilakukan menggunakan tikus yang sudah diberi pakan hiperkolesterolemia dan diinduksi triton $\mathrm{x}-100$ sebelumnya, yang mana berfungsi untuk meningkatkan kadar trigliserida darah pada tikus tersebut. Pemberian triton $\mathrm{x}-100$ dengan dosis 
20mg/200gramBB dapat meningkatkan kadar trigliserida darah dalam waktu 72 jam (Manodeep et al., 2012). Sehingga pada penelitian ini dilakukan pemeriksaan ulang kadar trigliserida darah hewan uji pada hari ke-3 setelah diinduksi untuk memastikan adanya kenaikan kadar trigliserida pada hewan uji.

Pada analisis data hari ke-10 didapatkan hasil nilai $\mathrm{p}=0,000$, maka nilai $\mathrm{p}<0,05$ sehingga terdapat perbedaan secara bermakna terhadap penurunan kadar trigliserida pada setiap kelompok. Dari hasil uji One Way ANOVA dapat disimpulkan bahwa hipotesis 1 peneliti diterima. Maka ekstrak etanol 96\% anggur merah dapat menurunkan kadar trigliserida pada hewan uji.

Berdasarkan uji statistik yang telah dilakukan, hasil penelitian menunjukkan terdapat perbedaan kadar trigliserida post-test yang bermakna padasemua kelompok uji dan antar kelompok kontrol. Kelompok P3 memiliki kadar trigliserida post-test yang paling rendah (97,2mg/dl) dibandingkan dengan P2 $(135,2 \mathrm{mg} /$ dl), dan P1 (147,4mg/dl). Efek penurunan kadar tigliseridaterhadap ekstrak etanol $96 \%$ anggur merah meningkat seiring dengan peningkatan dosis dengan dosis $500 \mathrm{mg} / 200 \mathrm{gramBB} /$ hari merupakan dosis yang memberikan penurunan terbesar dibandingkan dengan dosis $250 \mathrm{mg} / 200 \mathrm{gramBB} /$ hari dan dosis $100 \mathrm{mg} / 200$ gramBB.

Penghitungan penurunan kadar trigliserida darah setelah diberikan ekstrak, dihitung menggunakan persentase penurunan dengan rumus rata-rata kadar posttest kontrol negatif dikurang rata-rata kadar posttest kelompok perlakuan dan dibagi rata-rata kadar posttest kontrol negatif. Pada kelompok dosis $500 \mathrm{mg} / 200$ gramBB didapatakan penurunan sebesar 40,7\%. Pada kelompok dosis $250 \mathrm{mg} / 200$ gramBB penurunan sebasar $17,5 \%$. Pada kelompok dosis $100 \mathrm{mg} / 200$ gramBB didapatkan penurunan sebesar $10 \%$. Sedangkan pada kelompok kontrol positif penurunan sebesar $37,6 \%$.

Ekstrak etanol 96\% anggur merah dapat menurunkan kadar trigliserida darah melalui efek kandungan yang terdapat pada anggur merah yaitu Pterostilbene, kandungan pterostilbene pada anggur merah akan mengaktivasi PPAR- $\alpha$ yang akan menyebabkan peningkatan $\beta$-oksidasi asam lemak, peningkatan ekspresi gen lipoprotein lipase (LPL) dan penurunan sintesis Very Low Density Lipoprotein (VLDL) (Rimando et al., 2005).
Kandungan selanjutnya adalah resveratrol, dalam menurunkan kadar trigliserida dengan cara menghambat akumulasi lipid tersebut melalui 3 jalur yaitu dengan meningkatkan cAMP, menurunkan lipogenesis, meningkatkan AMP activated protein kinase (AMPK) (Lee et al., 2011). Selanjutnya yaitu proantosianidin yang mempunyai efek penurunan kadar trigliserida dengan cara mengurangi kadar apolipoprotein $\mathrm{B}$ (APO B), yang terdapat pada kilomikron, VLDL dan LDL yang mana fungsi dari APO B yaitu sebagai transport trigliserida di dalam darah (Orbayinah dan Kurnia, 2011).Likopen memiliki sifat anti kolesterol yang ditunjukkan melalui penghambatan aktifitas HMG-CoA reduktase (Winarsi, 2007).

Perbandingan antara kelompok perlakuan dosis 1,2 dan 3 yang mempunyai efek lebih besar dalam menurunkan kadar trigliserida adalah dosis 3, dikarenakan semakin tinggi dosis yang yang diberikan kandungan aktif yang terdapat dalam ekstrak anggur merah berupa pterostilbene (Amr, 2010), resveratrol (Szkudelska et al., 2009), proantosianidin (Nassiri dan Hosseintadeh, 2009) dan likopen (Winarsi, 2007) juga semakin banyak, sehingga kemampuan dalam menurunkan kadar trigliserida juga semakin besar.

Penelitian sebelumnya yang dilakukan Riyani (2011) didapatkan perbedaan kadar kolesterol total darah sebelum dan sesudah perlakuan, kelompok dosis I $248,69 \mathrm{mg} / \mathrm{dL}$ dan $181,11 \mathrm{mg} / \mathrm{dL}$, dosis II $248,71 \mathrm{mg} / \mathrm{dL}$ dan $155,39 \mathrm{mg} / \mathrm{dL}$, dosis III $246,64 \mathrm{mg} / \mathrm{dL}$ dan $140,79 \mathrm{mg} / \mathrm{dL}$. Pada penelitian yang dilakukan oleh Orbayinah dan Kurnia (2011), penurunan kadar trigliserida darah kelompok dosis I, II, III berturutturut yaitu $24,72 \%, 53,93 \%, 72,32 \%$. Sehingga disimpulkan bahwa penelitian ini sejalan dengan penelitian yang dilakukan oleh Riyani, Orbayinah dan Kurnia, bahwa ekstrak anggur merah dapat menurunkan kadar trigliserida, akan tetapi dosis 3 (500mg/200gramBB) yang mempunyai efek lebih besar dibandingkan dengan dosis 1 dan 2 .

Perbedaan antara penelitian ini dan penelitian sebelumnya yang dilakukan oleh Riyani (2011), Orbayinah dan Kurnia (2011) adalah etanol yang digunakan sebagai penyari pada penelitian ini yaitu 96\% sedangkan penelitian sebelumnya $70 \%$, diharapkan pada penyari yang digunakan 96\% lebih banyak menarik kandungan 
kimia metabolit sekunder dibandingkan metabolit primer, dikarenakan $96 \%$ yang berarti $96 \%$ etanol dan $4 \%$ air, etanol merupakan penyari yang universal untuk metabolit sekunder sedangkan air untuk menyari metabolit primer seperti asam amino, protein dan koarbohidrat.

Pada penelitian ini masih banyak kekurangan, salah satunya adalah kurangnya variasi dosis untuk menghasilkan dosis yang terbaik untuk menurunkan kadar trigliserida darah, adanya kemungkinan human eror dalam melakukan injeksi pemberian obat pada hewan uji, serta peran senyawa yang berperan aktif dari ekstrak etanol $96 \%$ anggur merah yang dapat menurunkan kadar trigliserida darah tidak dapat diketahui pasti sehingga mekanisme penurunan kadar trigliserida karena pemberian ekstrak juga tidak diketahui pasti.

Untuk penelitian selanjutnya hendaknya dilakukan dengan dosis yang tinggi dan masa perlakuan yang lebih lama untuk mengetahui dosis toksik, efek samping dan jangka waktu pemakaian yang efektif.Selain itu perlu dilakukan penelitian dengan pakan tinggi lemak yang diteruskan selama masa perlakuan untuk melihat efek hipolipidemik ekstrak anggur merah tanpa kombinasi diet.

\section{SIMPULAN}

\section{Simpulan}

1. Ekstrak etanol 96\%Anggur Merah (Vitis Vinifera) mempunyai efek terhadap penurunan kadar trigliserida darah pada tikus putih.

2. Ekstrak etanol 96\% Anggur Merah (Vitis Vinifera) dosis $500 \mathrm{mg} / 200$ gramBB memiliki efek yang lebih besar dibandingkan dengan dosis $250 \mathrm{mg} / 200$ gramBB dan dosis 100 $\mathrm{mg} / 200$ gramBB terhadap penurunan kadar trigliserida darah pada tikus putih.

3. Ekstrak etanol 96\% Anggur Merah (Vitis Vinifera) dosis $500 \mathrm{mg} / 200$ gramBB memiliki efek penurunan yang lebih besar dibandingkan dengan kontrol positif yang diberikan simvastatin.

\section{DAFTAR PUSTAKA}

Aaronson P.I dan Jeremy P.T.W. 2010. Hiperlipidemia in :At a Glance. $3^{\text {th }}$ ed. Jakarta, pp.78-9
Amr, 2010. Pterostilbene Monograf. Journal of Alternative Medicine Rewiew. 15:2

Cormack D.M., David M.F. 2013. A Review of Pterostilbene Antioxidant Activity and Disease Modification.PubMed.13:1

Hidayatulloh A., Ery I., Faizal F., Fitriatul I., Nurul F., Riefyan A., Santosa A.N., Syafira R.S., 2011. Hubungan Faktor Resiko Obesitas dengan Rasio Lingkar Pinggang Pinggul. BIMGI.1:48-9

Kanwil Departemen Kesehatan RI. 2007 Profil Kesehatan Sumatera Utara, Medan.http:// www.perpustakaan.depkes.go.id/cgi-bin/ koha/opacsearch.pl? $\quad \mathrm{q}=\mathrm{ccl}=\mathrm{su}:$ Health $\%$ 20\&offset $=640 \&$ sort by $=$ call number as. (Agustus 2015)

Kim J.K., Sung P.J., Young H.L., 2014. Antihyperlipidemic Effect of Rhapontin and Rhapontigenin form Rheum undulatum in Rats Fed a Hight-Cholesterol Diet. Planta Med. 80:1067

Lee M.J., Denis F., Kavithalakshmi S., Meenalakshmi M.M., Manli L., Jeffrey L.B., Goutam G.C., Balakuntalam S. 2011. Resveratrol Ameliorates High GlucoseInduced Protein Synthesis in Glomerular Epithelial Cells. Journal PMC.22:1-17

Manodeep C., Seema S.K., Jignasa P.S., Jagadish K.V. 2012.Antihyperlipidemic Activity of Divya Methipachak Againts Triton X-100 Induced Hyperlipidemia in Rats.International Reaserch Journal of Pharmacy. 1:226-9

Nassiri A.M., Hosseinzadeh H., 2009. Review of the Pharmacological Effect of Vitis Vinifera (Grape) and its Bioactive Compounds. PubMed.9:1197

Nasution L.S., 2013. Pengaruh Pemberian Likopen terhadap Perkembangan Lesi Aterosklerosis pada Tikus Hiperkolesterolemia.Jurnal Kedokteran dan Kesehatan.9:2

Orbayinah S., Kurnia E.P., 2011. Pengaruh Ekstrak Buah Anggur Merah (Vitis Vinifera L) terhadap Kadar Trigliserida Tikus Putih (Rattus Novergicus).Jurnal Mutiara Medika. 11:3 
Riayani S., 2011. Pengaruh Ekstrak Anggur Merah (Vitis Vinifera) terhadap Kadar Kolesterol Total Darah Tikus Putih (Rattus Novergicus).Skripsi. Yogyakarta: Fakultas Kedokteran dan Ilmu Kesehatan, Universitas Muhammadiyah Yogyakarta

Rimando A.M., Rangaswamy N., Dennis R., Feller, Wallace Y., 2005. Pterostilbene, a New Agonist for the Peroxisome ProliferatorActivated Receptor $\alpha$-Isoform, Lowers Plasma Lipoproteins and Cholesterol in Hypercholesterolemic Hamster. Journal of Agricultural and Food Chemistry.53:3403-7

Szkudelska K., Nogoeski L., Szkudelski T. 2009. Resveratro, a naturally Occurring Diphenolic Compound, Affect Lipogenesis, Lipolysis and the Antilipolytic action of Insulin in Isolated rat Adipocytes. Journal of Steroid Biochemistry andMolecular Biology.113:17-24
Tsalissavrina I., Djoko W., Dian H., 2006. Penagruh Pemberian Diet Tinggi Karbohidrat Dibandingkan Diet Tinggi Lemak Terhadap Kadar Trigliserida dan HDL Darah.Jurnal Kedokteran Brawijaya.22:80

World Health Organization, 2011.Global Status Report on Noncommunicable Disease 2010. http://www.who.int/nmh/publications/ncd report full en.pdf (Agustus 2015)

Winarsi H. 2007. Antioksidan Alami dan Radikal Bebas : Potenti dan Aplikasinya dalam Kesehatan. Yogyakarta : Kanisium, pp.113 